\title{
SURVIVAL AND GROWTH OF MAHOGANY SEEDLINGS UNDER A NURSE CROP WITH DIFFERENT CANOPY OPENINGS
}

\author{
R M Mahroof, J P Edirisinghe and Caroline Hauxswell \\ Department of Zoology, University of Peradeniya \\ Institute of Ecology \& Resource Management, University of Edinburgh
}

Swietenia matrophylla King is one of the luxury class timhers of the world. The survival and growth of S. marrophylla when planted under the nurse crop. Aracia anriculiformis with different canopy openings was determined. The study was carried out in a 9 year old Acuciu plantation established by the Forest Department on a degraded, hilly land at Natliyapana in Kegalle. Two experimental blocks (replicates) about $1 \mathrm{~km}$ apart were selected for the study. In each block 3 plots $(5 \times 5 \mathrm{~m})$ were selected on the basis of canopy openings (open, moderate, closed) by removal of trees and branches. Within each plot 18 mahogany sedlings were planted. The photosynthetically active radiation at each canopy opening was measured using a data logger with PAR light sensors. The mean survival level of seedlings was found to be $83 \%$ (open gap-61\% PAR). 97\% (moderate gap-43\% PAR) and 94\% (closed gap- 24\% PAR). Height of seedlings measured monthly indicated an increase in height with high light intensity. Similarly, the root collar diameter measured 9 months after planting varied from $1.2 \mathrm{~cm}$ (open canopy), $0.98 \mathrm{~cm}$ (moderate canopy) to $0.71 \mathrm{~cm}$ (closed canopy). The mean number of leaves per plant under open canopy was 15, and 11 under moderate and closed canopy. Datat obtained so far indicate that survival is low under open canopy with high light intensity, while growth is better under open canopy inferring that shade is important only during the initial establishment phase of seedlings and not thereatter. However, there are reports of high damage by the mahogany shoot borer (Hypsipyla robusta Moore) when grown in the open. 